ISSN 0258-7122 (Print), 2408-8293 (Online)

Bangladesh J. Agril. Res. 41(3): 451-460, September 2016

\title{
EFFECT OF OSMOPRIMING ON GERMINATION OF RICE SEED
}

\author{
M. N. HASAN ${ }^{1}$, M. A. SALAM ${ }^{2}$, M. M. I. CHOWDHURY ${ }^{3}$ \\ M. SULTANA ${ }^{4}$ AND N. ISLAM ${ }^{5}$
}

\begin{abstract}
The experiment was conducted at the Seed Laboratory, Department of Agronomy, Bangladesh Agricultural University, Mymensingh during the period from September to October, 2011 to study the effect of chemical priming of seed on germination and growth of rice seedling cv. BRRI dhan 29. Seeds were soaked in $3 \%$ and $5 \%$ solutions of $\mathrm{CaCl}_{2}, \mathrm{ZnSO}_{4}$ and $\mathrm{KCl}$ for $24,30,36,42,48$, 54, 60 hours, respectively. A control was maintained where seeds were subjected to no priming treatment. The experiment was laid out in a Completely Randomized Design with three replications. Primed seeds were tested for germination and vigour on sandy soil media (60:40) in petridish under field capacity. Seed quality tests included mean germination time, shoot length, shoot dry mass, root length and root dry mass. The results revealed that priming treatments had significant influence on germination and all the growth parameters of rice seedlings. Priming with $3 \% \mathrm{ZnSO}_{4}$ for 30 hours showed the highest germination percentage and the lowest mean germinaion time. Priming with $5 \% \mathrm{KCl}$ for 54 hours showed the highest root length while $5 \%$ of the same solution for 24 hours showed the highest root dry mass. On the contrary, seeds having no priming treatment showed the lowest values for germination, vigour index, shoot length,shoot dry mass, root length and root dry mass and the highest mean germination time. The present study concludes that rice seed cv. BRRI dhan29 could be primed with $3 \% \mathrm{ZnSO}_{4}$ solution for 30 hours for improving germination and seedling growth.
\end{abstract}

Keyword: Priming, germination, seed vigour and rice seedlings.

\section{Introduction}

Rice (Oryza sativa) is one of the most extensively cultivated cereals of the world. It is the principal food crop of Bangladesh and constitutes $95 \%$ of food grain production in this country. At the end of the 2008 global rice reserve is estimated at 102.4 million tons, which would be fall or 1.2 million tons from already two opening level while rice production in 2007 indicated $4.0 \%$ increase over 2006 (Rahman et al., 2009). About half of the world's population live on rice, so global food production needs to be doubled in order to feed the nonstop

${ }^{1}$ Former student of Agronomy, Bangladesh Agricultural University (BAU), ${ }^{2}$ Former Director General of Bangladesh Institute of Nuclear Agriculture, ${ }^{3}$ Scientific Officer of On Farm Research Division, Bangladesh Agricultural Research Institute, Bogra, Bangladesh, ${ }^{4}$ Scientific Officer of Tuber Crops Research Sub-Center, Bangladesh Agricultural Research Institute, Bogra, Bangladesh, ${ }^{5}$ Prof. Dept. of Agronomy, Bangladesh Agricultural University. 
mounting mouth of the word. In many Asian countries, incuding Bangladesh rice provides food and livelihood security where it is the staple food. Bangladesh is predominately a rice based country as she earns about $21.10 \%$ of her gross domestic product (GDP) from Agriculture (Anon.,2008). Rice production depend on a lot of factors. Quality seed is one of the important factors for production of rice. A good seed with in a variety gives good stand establishment in the soil, which in turn ensures a good harvest. Seed quality is a multiple concept comprising several components (Thomson, 1979) like germination capacity, viability, vigour, moisture content and seed health. Quality seed insures quality seedling. It is an important and obligatory input to maintain optimum growth and better grain yield for mordern rice varieties (BRRI, 2006). Optimum crop stand establishment is the pre-requisite for successful production. Crops often fail to establish quickly and uniformly, leading to decreased yield, because of low plant population, constraints to good establishment of crops includes lake of soil moisture, low or high temperature, soil salinity, weed competition, low seed quality and extreme disease pressure. Seeds that germinate faster and rapidly are able to produce sufficient deep root system before the seed beds dired out and these seedlings have enough competitive ability against weed and seedling diseases. If seeds are soaked in different chemical solutions, germination happens more quickly, resulting in a healthier crop. Germination and seedling vigour are appraised on the basis of important physiological and biochemical attributes mainly related to the rapidity of germination, vigourous seedling and reserve metabolism pattern. Priming treatments have been found to enhance the amylase activity,which is positively correlated with the reserve mobilization and germination rate in rice (Lee and Kim, 2000; Basar et al., 2005). Priming increases level of a-amylase activity was reported by Basar et al. (2005) in hardened rice seeds. Good seedling establishment is an important constraint to crop production in the semi-arid tropics (Harris et al., 1999). Priming in the semiarid tropics has been reported to increase emergence and improvement of stand, more vigourous plants, better drought tolerance, earlier maturing and higher grain yield (Harris et al., 1999, 2001,2002). Osmo-hardening with $\mathrm{KCl}$ or $\mathrm{CaCl}_{2}$ for 12 $\mathrm{h}$ improved emergence, stand establishment, tiller number, grain and straw yields and harvest index. However, seed priming techniques did not affect plant height, number of spikelets, number of grains and 1000-grain weight. Improved yield was attributed principally to better stand establishment and improved number of fertile tillers (Farooq et al., 2008). Chemical priming partically ensured rapid and uniform germination and seedling growth. The above discussion indicates that chemical priming of seed is an effective tool for rapid and uniform seedling emergence. However, methods for priming of rice have not yet been developed in bangladesh. Hence, the present study was undertaken with an objective to study the effect of chemical priming of rice seed for germination and vigour. 


\section{Materials and Methods}

The experiment was conducted at the Seed Laboratory of the Department of Agronomy, Bangladesh Agricultural University (BAU), Mymensingh during the period from September to Octobaer, 2011. The experiment was laid out in a Completely Randomized Design with three replications. In this experiment, seeds of rice variety BRRI dhan 29 was used as the test material. Rice seeds were soaked in $3 \%$ and $5 \%$ solutions of $\mathrm{Cacl}_{2}, \mathrm{ZnSO}_{4}$ and $\mathrm{KCl}$ for 24, 30, 36, 42, 48, 54 and 60 hours respectively at room temperature $(27+3)$ The seeds were then dired at room temperature and were used in the further tests. A control was maintained where seeds were not primed. Therefore, there were 43 treatment combinations as follows-

$\mathrm{T}_{1}=$ Priming with $3 \%$ solution of $\mathrm{CaCl}_{2}$ for $24 \mathrm{hrs}, \mathrm{T}_{2}=$ Priming with $3 \%$ solution of $\mathrm{CaCl}_{2}$ for $30 \mathrm{hrs}, \mathrm{T}_{3}=$ Priming with $3 \%$ solution of $\mathrm{CaCl}_{2}$ for $36 \mathrm{hrs}$, $\mathrm{T}_{4}=$ Priming with $3 \%$ solution of $\mathrm{CaCl}_{2}$ for $42 \mathrm{hrs}, \mathrm{T}_{5}=$ Priming with $3 \%$ solution of $\mathrm{CaCl}_{2}$ for $48 \mathrm{hrs}, \mathrm{T}_{6}=$ Priming with $3 \%$ solution of $\mathrm{CaCl}_{2}$ for $54 \mathrm{hrs}$, $\mathrm{T}_{7}=$ Priming with $3 \%$ solution of $\mathrm{CaCl}_{2}$ for $60 \mathrm{hrs}, \mathrm{T}_{8}=$ Priming with $5 \%$ solution of $\mathrm{CaCl}_{2}$ for $24 \mathrm{hrs}, \mathrm{T}_{9}=$ Priming with $5 \%$ solution of $\mathrm{CaCl}_{2}$ for $30 \mathrm{hrs}$, $\mathrm{T}_{10}=$ Priming with $5 \%$ solution of $\mathrm{CaCl}_{2}$ for $36 \mathrm{hrs}, \mathrm{T}_{11}=$ Priming with $5 \%$ solution of $\mathrm{CaCl}_{2}$ for $42 \mathrm{hrs}, \mathrm{T}_{12}=$ Priming with $5 \%$ solution of $\mathrm{CaCl}_{2}$ for $48 \mathrm{hrs}$, $\mathrm{T}_{13}=$ Priming with $5 \%$ solution of $\mathrm{CaCl}_{2}$ for $54 \mathrm{hrs}, \mathrm{T}_{14}=$ Priming with $5 \%$ solution of $\mathrm{CaCl}_{2}$ for $60 \mathrm{hrs}, \mathrm{T}_{15}=$ Priming with $3 \%$ solution of $\mathrm{ZnSO}_{4}$ for $24 \mathrm{hrs}$, $\mathrm{T}_{16}=$ Priming with $3 \%$ solution of $\mathrm{ZnSO}_{4}$ for $30 \mathrm{hrs}, \mathrm{T}_{17}=$ Priming with $3 \%$ solution of $\mathrm{ZnSO}_{4}$ for $36 \mathrm{hrs}, \mathrm{T}_{18}=$ Priming with $3 \%$ solution of $\mathrm{ZnSO}_{4}$ for 42 hrs, $\mathrm{T}_{19}=$ Priming with $3 \%$ solution of $\mathrm{ZnSO}_{4}$ for $48 \mathrm{hrs}, \mathrm{T}_{20}=$ Priming with $3 \%$ solution of $\mathrm{ZnSO}_{4}$ for $54 \mathrm{hrs}, \mathrm{T}_{21}=$ Priming with 3\% solution of $\mathrm{ZnSO}_{4}$ for 60 hrs, $\mathrm{T}_{22}=$ Priming with 5\% solution of $\mathrm{ZnSO}_{4}$ for $24 \mathrm{hrs}, \mathrm{T}_{23}=$ Priming with 5\% solution of $\mathrm{ZnSO}_{4}$ for $30 \mathrm{hrs}, \mathrm{T}_{24}=$ Priming with $5 \%$ solution of $\mathrm{ZnSO}_{4}$ for 36 hrs, $\mathrm{T}_{25}=$ Priming with $5 \%$ solution of $\mathrm{ZnSO}_{4}$ for $42 \mathrm{hrs}, \mathrm{T}_{26}=$ Priming with $5 \%$ solution of $\mathrm{ZnSO}_{4}$ for $48 \mathrm{hrs}, \mathrm{T}_{27}=$ Priming with $5 \%$ solution of $\mathrm{ZnSO}_{4}$ for 54 hrs, $\mathrm{T}_{28}=$ Priming with $5 \%$ solution of $\mathrm{ZnSO}_{4}$ for $60 \mathrm{hrs}, \mathrm{T}_{29}=$ Priming with $3 \%$ solution of $\mathrm{KCl}$ for $24 \mathrm{hrs}, \mathrm{T}_{30}=$ Priming with $3 \%$ solution of $\mathrm{KCl}$ for $30 \mathrm{hrs}, \mathrm{T}_{31}$ $=$ Priming with $3 \%$ solution of $\mathrm{KCl}$ for $36 \mathrm{hrs}, \mathrm{T}_{32}=$ Priming with $3 \%$ solution of $\mathrm{KCl}$ for $42 \mathrm{hrs}, \mathrm{T}_{33}=$ Priming with $3 \%$ solution of $\mathrm{KCl}$ for $48 \mathrm{hrs}, \mathrm{T}_{34}=$ Priming with $3 \%$ solution of $\mathrm{KCl}$ for $54 \mathrm{hrs}, \mathrm{T}_{35}=$ Priming with $3 \%$ solution of $\mathrm{KCl}$ for $60 \mathrm{hrs}, \mathrm{T}_{36}=$ Priming with $5 \%$ solution of $\mathrm{KCl}$ for $24 \mathrm{hrs}, \mathrm{T}_{37}=$ Priming with $5 \%$ solution of $\mathrm{KCl}$ for $30 \mathrm{hrs}, \mathrm{T}_{38}=$ Priming with $5 \%$ solution of $\mathrm{KCl}$ for $36 \mathrm{hrs}, \mathrm{T}_{39}$ $=$ Priming with $5 \%$ solution of $\mathrm{KCl}_{4}$ for $42 \mathrm{hrs}, \mathrm{T}_{40}=$ Priming with $5 \%$ solution of $\mathrm{KCl}$ for $48 \mathrm{hrs}, \mathrm{T}_{41}=$ Priming with $5 \%$ solution of $\mathrm{KCl}$ for $54 \mathrm{hrs}, \mathrm{T}_{42}=$ Priming with $5 \%$ solution of $\mathrm{KCl}$ for $60 \mathrm{hrs}, \mathrm{T}_{42}=$ No priming (control)

Sterilized sand was used as germination media and Petidish was used as germination media and Petidish was used as container. The moisture content of 
the media was maintained at $60 \%$ of the capacity. The following seed quality parameters were measured: 1 . Germination \%, 2.Mean germination time, 3 . Vigour index by Seedling Vigour Classification Test (Germination\% $\mathrm{x}$ average seedling length), 4. Seedling shoot length $(\mathrm{cm}), 5$. Seedling root length $(\mathrm{cm}), 6$. Seedling shoot dry mass (mg) and 7. Seedling root dry mass $(\mathrm{mg})$. The collected data were compiled and analyzed statistically using the analysis of variance (ANOVA) technique and the means were compared by Duncan's Multiple Range Test (Gomez and Gomez, 1984).

\section{Result and Discussion}

\section{Germination}

Table 1 revealed that germination of rice seedlings was significantly affected due to the priming treatment. The germination of seed for different treatments ranged between 71 and 96.67 percentanges. The highest germination $(95.67 \%)$ was obtained in seed primed with $3 \% \mathrm{ZnSO}_{4}$ for 30 hours whereas the lowest value of germination $(60 \%)$ was found in non-primed seed. This result is similar to that of Farooq et al. (2006a). Osmo-hardening with $\mathrm{KCl}$ performed better than all other treatments including control. Priming improved the $\mathrm{K}^{+}$balance that activates alpha-amylase, a basis for seed in vigouration. Osmo-hardening with $\mathrm{KCl}$ in another experiment (Farooq et al., 2006c). The results of the present study clearly showed that more germination adventages of rice seed could be achieved by priming with different chemicals.

\section{Mean germination time}

It is found that priming treatments had significant effect on mean germination time (days) of rice seedlings for different chemical treatments (Table 1). The mean germination time of seed for different treatments ranged from 4.0109 to 7.6224 days. Under all the treatments, the highest mean germination time was found with non-primed seed. The lowest mean germination time for priming with $5 \% \mathrm{ZnSO}_{4}$ for 24 hours. The results revealed that priming enhanced rapid germination of seed comared with non-primed seed. The significant enhancement in germination might have been caused due to increased amylase activity that is positively correlated with the reserve mobilization and mean germination rate in rice Lee and Kim,2000). The results revealed that primed seed emerged faster and decreased the mean germination time. Similar results were also found by Harris et al. (2001).

\section{Vigour index}

The vigour index (VI) of rice seedlings was affected significantly by priming with different chemical treatments (Table 1). The vigour index of the seed for different treatments ranged from 10.5519 to 25.1913. At all conditions, the 
highest vigour index was found with the seed primed with $5 \% \mathrm{ZnSO}_{4}$ for 24 hours. On the other hand the lowest vigour index was found with non-primed seed. The results showed that vigour index increased in primed seeds. The vigour index increase might be related to reduction of imbibition of lag time for priming treatment (Bradford, 1986). Priming also causes physiological and bio-chemical changes in seed during the seed treatments and metabolic activities increases aamylase activity, thus indicating higher vigour index (Lee and Kim, 2003). The results showed that priming increased the vigour index of seed. This result is similar to that of Harris et al. (2000), lee and Kim (2000) and Basar et al. (2003).

Table 1. Effect of chemical priming of rice seed on germinatin (\%), mean germination time and vigour index

\begin{tabular}{l|l|l|l|l}
\hline \multirow{2}{*}{ No. } & \multirow{2}{*}{ Seed Priming treatment } & \multicolumn{3}{|c}{ Growth parameters } \\
\cline { 3 - 5 } & & Germination $(\%)$ & $\begin{array}{c}\text { Mean } \\
\text { germination time }\end{array}$ & vigour index \\
\hline 1 & $3 \% \mathrm{CaCl}_{2}$ for $24 \mathrm{H}$ & $71 \mathrm{k}-\mathrm{l}$ & $6.7863 \mathrm{a}-\mathrm{f}$ & $12.419 \mathrm{~h}-\mathrm{j}$ \\
2 & $3 \% \mathrm{CaCl}_{2}$ for $30 \mathrm{H}$ & $84 \mathrm{a}-\mathrm{j}$ & $5.0369 \mathrm{c}-\mathrm{h}$ & $19.7208 \mathrm{a}-\mathrm{g}$ \\
3 & $3 \% \mathrm{CaCl}_{2}$ for $36 \mathrm{H}$ & $85.33 \mathrm{a}-\mathrm{j}$ & $5.3594 \mathrm{a}-\mathrm{h}$ & $18.6734 \mathrm{a}-\mathrm{i}$ \\
4 & $3 \% \mathrm{CaCl}_{2}$ for $42 \mathrm{H}$ & $80.67 \mathrm{~d}-\mathrm{l}$ & $5.5725 \mathrm{a}-\mathrm{h}$ & $17.8110 \mathrm{~b}-\mathrm{j}$ \\
5 & $3 \% \mathrm{CaCl}_{2}$ for $48 \mathrm{H}$ & $93.33 \mathrm{a}-\mathrm{c}$ & $4.9468 \mathrm{~d}-\mathrm{h}$ & $22.2772 \mathrm{a}-\mathrm{d}$ \\
6 & $3 \% \mathrm{CaCl}_{2}$ for $54 \mathrm{H}$ & $87.33 \mathrm{a}-\mathrm{i}$ & $5.2482 \mathrm{a}-\mathrm{h}$ & $20.0955 \mathrm{a}-\mathrm{g}$ \\
7 & $3 \% \mathrm{CaCl}_{2}$ for $60 \mathrm{H}$ & $75 \mathrm{i}-\mathrm{l}$ & $7.6224 \mathrm{a}$ & $11.8872 \mathrm{i}-\mathrm{j}$ \\
8 & $5 \% \mathrm{CaCl}_{2}$ for $24 \mathrm{H}$ & $76.67 \mathrm{~g}-\mathrm{l}$ & $5.8588 \mathrm{a}-\mathrm{h}$ & $15.2882 \mathrm{e}-\mathrm{j}$ \\
9 & $5 \% \mathrm{CaCl}_{2}$ for $30 \mathrm{H}$ & $86 \mathrm{a}-\mathrm{j}$ & $5.1686 \mathrm{c}-\mathrm{h}$ & $20.0171 \mathrm{a}-\mathrm{g}$ \\
10 & $5 \% \mathrm{CaCl}_{2}$ for $36 \mathrm{H}$ & $78 \mathrm{f}-\mathrm{l}$ & $6.0497 \mathrm{a}-\mathrm{h}$ & $15.1530 \mathrm{e}-\mathrm{j}$ \\
11 & $5 \% \mathrm{CaCl}_{2}$ for $42 \mathrm{H}$ & $94.67 \mathrm{a}-\mathrm{b}$ & $4.5616 \mathrm{e}-\mathrm{h}$ & $24.07132 \mathrm{a}-\mathrm{b}$ \\
12 & $5 \% \mathrm{CaCl}_{2}$ for $48 \mathrm{H}$ & $86.33 \mathrm{a}-\mathrm{j}$ & $5.9312 \mathrm{a}-\mathrm{h}$ & $16.3392 \mathrm{~d}-\mathrm{j}$ \\
13 & $5 \% \mathrm{CaCl}_{2}$ for $54 \mathrm{H}$ & $86.33 \mathrm{a}-\mathrm{j}$ & $4.9734 \mathrm{~d}-\mathrm{h}$ & $20.0911 \mathrm{~d}-\mathrm{j}$ \\
14 & $5 \% \mathrm{CaCl}_{2}$ for $60 \mathrm{H}$ & $92 \mathrm{a}-\mathrm{d}$ & $5.8124 \mathrm{a}-\mathrm{h}$ & $18.9476 \mathrm{a}-\mathrm{j}$ \\
15 & $3 \% \mathrm{ZnSO}_{4}$ for $24 \mathrm{H}$ & $85.33 \mathrm{a}-\mathrm{j}$ & $6.4199 \mathrm{a}-\mathrm{g}$ & $17.8286 \mathrm{~b}-\mathrm{i}$ \\
16 & $3 \% \mathrm{ZnSO}_{4}$ for $30 \mathrm{H}$ & $95.67 \mathrm{a}$ & $4.9132 \mathrm{~d}-\mathrm{h}$ & $22.9472 \mathrm{a}-\mathrm{d}$ \\
17 & $3 \% \mathrm{ZnSO}_{4}$ for $36 \mathrm{H}$ & $93.67 \mathrm{a}-\mathrm{c}$ & $4.4887 \mathrm{f}-\mathrm{h}$ & $24.1658 \mathrm{a}-\mathrm{b}$ \\
18 & $3 \% \mathrm{ZnSO}_{4}$ for $42 \mathrm{H}$ & $90.678 \mathrm{a}-\mathrm{e}$ & $4.1590 \mathrm{~g}-\mathrm{h}$ & $23.8403 \mathrm{a}-\mathrm{c}$ \\
19 & $3 \% \mathrm{ZnSO}_{4}$ for $48 \mathrm{H}$ & $91.678 \mathrm{a}-\mathrm{d}$ & $5.4032 \mathrm{a}-\mathrm{h}$ & $20.1372 \mathrm{a}-\mathrm{g}$ \\
20 & $3 \% \mathrm{ZnSO}_{4}$ for $54 \mathrm{H}$ & $78.33 \mathrm{e}-\mathrm{l}$ & $7.2224 \mathrm{a}-\mathrm{d}$ & $13.7988 \mathrm{f}-\mathrm{j}$ \\
21 & $3 \% \mathrm{ZnSO}_{4}$ for $60 \mathrm{H}$ & 70.331 & $6.7317 \mathrm{a}-\mathrm{f}$ & $12.558 \mathrm{~h}-\mathrm{j}$ \\
22 & $5 \% \mathrm{ZnSO}_{4}$ for $24 \mathrm{H}$ & $94 . \mathrm{a}-\mathrm{d}$ & $4.0109 \mathrm{~h}$ & $25.1913 \mathrm{a}$ \\
23 & $5 \% \mathrm{ZnSO}_{4}$ for $30 \mathrm{H}$ & $85.33 \mathrm{a}-\mathrm{j}$ & $5.63936 \mathrm{a}-\mathrm{h}$ & $18.9149 \mathrm{a}-\mathrm{h}$ \\
24 & $5 \% \mathrm{ZnSO}_{4}$ for $36 \mathrm{H}$ & $90.67 \mathrm{a}-\mathrm{e}$ & $4.3023 \mathrm{~g}-\mathrm{h}$ & $24.0624 \mathrm{a}-\mathrm{b}$ \\
\hline
\end{tabular}


Table 1. Cont'd.

\begin{tabular}{|c|c|c|c|c|}
\hline \multirow[b]{2}{*}{ No. } & \multirow[b]{2}{*}{ Seed Priming treatment } & \multicolumn{3}{|c|}{ Growth parameters } \\
\hline & & Germination (\%) & $\begin{array}{c}\text { Mean } \\
\text { germination time }\end{array}$ & vigour index \\
\hline 25 & $5 \% \mathrm{ZnSO}_{4}$ for $42 \mathrm{H}$ & $93.67 \mathrm{a}-\mathrm{c}$ & 5.2094 b-h & 20.5260 a-f \\
\hline 26 & $5 \% \mathrm{ZnSO}_{4}$ for $48 \mathrm{H}$ & 90 a-f & 5.6136 a-h & $18.5260 \mathrm{a}-\mathrm{f}$ \\
\hline 27 & $5 \% \mathrm{ZnSO}_{4}$ for $54 \mathrm{H}$ & $83.33 \mathrm{a}-\mathrm{j}$ & $5.9603 \mathrm{a}-\mathrm{h}$ & $17.3942 \mathrm{~b}-\mathrm{i}$ \\
\hline 28 & $5 \% \mathrm{ZnSO}_{4}$ for $60 \mathrm{H}$ & 89 a-g & $5.0507 \mathrm{a}-\mathrm{h}$ & $18.4316 \mathrm{a}-\mathrm{i}$ \\
\hline 29 & $3 \% \mathrm{KCl}$ for $24 \mathrm{H}$ & $82.67 \mathrm{~b}-\mathrm{k}$ & 5.007 d-h & 19.0176 a-h \\
\hline 30 & $3 \% \mathrm{KCl}$ for $30 \mathrm{H}$ & $83.33 \mathrm{a}-\mathrm{j}$ & 6.2408 a-h & $16.85141-\mathrm{k}$ \\
\hline 31 & $3 \% \mathrm{KCl}$ for $36 \mathrm{H}$ & $81.64 \mathrm{c}-1$ & $6.0815 \mathrm{a}-\mathrm{h}$ & $16.2277 \mathrm{~d}-\mathrm{j}$ \\
\hline 32 & $3 \% \mathrm{KCl}$ for $42 \mathrm{H}$ & $86.67 \mathrm{a}-\mathrm{g}$ & $5.1412 \mathrm{c}-\mathrm{h}$ & $19.5361 \mathrm{a}-\mathrm{g}$ \\
\hline 33 & $3 \% \mathrm{KCl}$ for $48 \mathrm{H}$ & $91 \mathrm{a}-\mathrm{d}$ & $5.1148 \mathrm{c}-\mathrm{h}$ & $21.2382 \mathrm{a}-\mathrm{e}$ \\
\hline 34 & $3 \% \mathrm{KCl}_{4}$ for $54 \mathrm{H}$ & $90.33 \mathrm{a}-\mathrm{f}$ & 5.3876 a-h & 20.6484 a-f \\
\hline 35 & $3 \% \mathrm{KCl}$ for $60 \mathrm{H}$ & $85 a-j$ & $5.4091 \mathrm{a}-\mathrm{h}$ & $18.5118 \mathrm{a}-1$ \\
\hline 36 & $5 \% \mathrm{KCl}$ for $24 \mathrm{H}$ & $87 \mathrm{a}-\mathrm{i}$ & $5.6401 \mathrm{a}-\mathrm{h}$ & $18.7931 \mathrm{a}-\mathrm{h}$ \\
\hline 37 & $5 \% \mathrm{KCl}$ for $30 \mathrm{H}$ & $87.33 \mathrm{a}-\mathrm{i}$ & $6.78301 \mathrm{a}-\mathrm{f}$ & $14.943 \mathrm{e}-\mathrm{j}$ \\
\hline 38 & $5 \% \mathrm{KCl}$ for $36 \mathrm{H}$ & 83 b-k & $5.5405 \mathrm{a}-\mathrm{h}$ & $17.6437 \mathrm{~b}-\mathrm{j}$ \\
\hline 39 & $5 \% \mathrm{KCl}$ for $42 \mathrm{H}$ & $86.67 \mathrm{a}-\mathrm{j}$ & $6.2992 \mathrm{a}-\mathrm{h}$ & $17.3441 \mathrm{~b}-\mathrm{i}$ \\
\hline 40 & $5 \% \mathrm{KCl}_{4}$ for $48 \mathrm{H}$ & $88.33 \mathrm{a}-\mathrm{h}$ & $6.1029 \mathrm{a}-\mathrm{h}$ & $17.0403 \mathrm{c}-\mathrm{j}$ \\
\hline 41 & $5 \% \mathrm{KCl}$ for $54 \mathrm{H}$ & $75 \mathrm{i}-1$ & $7.4204 \mathrm{a}-\mathrm{c}$ & $12.4572 \mathrm{~h}-\mathrm{j}$ \\
\hline 42 & $5 \% \mathrm{KCl}$ for $60 \mathrm{H}$ & $76.33 \mathrm{~h}-1$ & $6.8847 \mathrm{a}-\mathrm{e}$ & $12.3292 \mathrm{~g}-\mathrm{h}$ \\
\hline \multirow[t]{3}{*}{43} & No Priming & $74.33 \mathrm{j}-1$ & $7.5858 \mathrm{a}-\mathrm{b}$ & $10.5519 \mathrm{j}$ \\
\hline & Level of Significant & $* *$ & $* *$ & $* *$ \\
\hline & $\mathrm{CV}(\%)$ & 78.28 & 12.69 & 24.48 \\
\hline
\end{tabular}

$* *=$ Significant at $1 \%$ level of probability, $*=$ Significant at $5 \%$ level of probability, $\mathrm{CV}=\mathrm{Co}$-efficient of variation .

\section{Shoot lenghth}

Table 2 revealed that shoot length of rice seedling was significant at significant at moist sandy condition in the priming treatments. The shoot length of rice seedlings for different treatments ranged from $10.26 \mathrm{~cm}$ to $12.42 \mathrm{~cm}$. At all the conditions, the highest shoot length $(12.43 \mathrm{~cm})$ was found in seed primed with $3 \% \mathrm{ZnSO}_{4}$ for 30 hours. On the other hand, the lowest shoot length was found in $5 \% \mathrm{KCl}$ for 48 hours. The results of the present study clearly showed that priming enhanced shoot length of rice for soil with moisture stress conditions. This result is in agreement with that of Tongma et al. (2001) and Farooq et al. (2006b).

\section{Shoot dry mass}

Seed priming treatments influenced significantly the growth of shoots dry mass of rice seedlings (Table 2). The shoot dry mass of rice seedlings for different 
treatments ranged from 0.04 to $.08 \mathrm{mg}$. The highest shoot dry mass of rice seedlings $(0.8 \mathrm{mg})$ was obtained in seed primed with $5 \% \mathrm{CaCl}_{2}$ for 24 hours whereas the lowest shoot dry mass of rice seedlings $(0.4 \mathrm{mg})$ was found in no primed seed. The lowest shoot dry mass was found in no primed seed. Seed priming increased seedling dry mass probably by enhancing $\mathrm{K}^{+}$condition in both seeds and seedlings, leading to improved a-amylase activity and the concentration of reducing sugars with amylase activity (Faurooq et al., 2007). The results clearly exhibited that seed priming had effect on shoot dry mass growth. The result of the present study is in agreement with that of Farooq et al. (2006b, 2007 and 2008) and Tongma et al. (2001).

\section{Root length}

The root length of rice seedling was affected signficaantly due to the priming treatments (Table 2). The root length of seedling for different treatments ranged from 8.147 to $10.14 \mathrm{~cm}$. The highest root length $(10.14 \mathrm{~cm})$ was optained in seed primed with $5 \% \mathrm{KCl}$ for 54 hours whereas the lowest root length $(8.147 \mathrm{~cm})$ was found in non-primed seed. The results of the present study showed that root length of rice seedling increased by priming treatments. Similar result was reported by Ruan et al. (2002).

Table 2. Effect of chemical priming on shoot length $(\mathrm{cm})$, shoot weight $(\mathrm{mg})$, root length $(\mathrm{cm})$ and root weight $(\mathrm{mg})$ of rice

\begin{tabular}{|c|c|c|c|c|c|}
\hline \multirow[b]{2}{*}{ No. } & \multirow{2}{*}{$\begin{array}{l}\text { Seed Priming } \\
\text { treatment }\end{array}$} & \multicolumn{4}{|c|}{ Growth parameters } \\
\hline & & $\begin{array}{l}\text { Shoot length } \\
\quad(\mathrm{cm})\end{array}$ & $\begin{array}{c}\text { Shoot dry } \\
\text { weight }(\mathrm{mg})\end{array}$ & $\begin{array}{c}\text { Root length } \\
(\mathrm{cm})\end{array}$ & $\begin{array}{c}\text { Root dry } \\
\text { weight }(\mathrm{mg})\end{array}$ \\
\hline 1 & $3 \% \mathrm{CaCl}_{2}$ for $24 \mathrm{H}$ & $10.37 \mathrm{~b}$ & 0.05333 c-e & 9.160 a-h & $0.04333 \mathrm{~d}-\mathrm{e}$ \\
\hline 2 & $3 \% \mathrm{CaCl}_{2}$ for $30 \mathrm{H}$ & $10.27 \mathrm{~b}$ & $0.06667 \mathrm{a}-\mathrm{d}$ & $9.393 \mathrm{a}-\mathrm{f}$ & $0.06667 \mathrm{a}-\mathrm{d}$ \\
\hline 3 & $3 \% \mathrm{CaCl}_{2}$ for $36 \mathrm{H}$ & $10.51 \mathrm{~b}$ & $0.0700 \mathrm{a}-\mathrm{d}$ & $9.560 \mathrm{a}-\mathrm{f}$ & $0.06667 \mathrm{a}-\mathrm{d}$ \\
\hline 4 & $3 \% \mathrm{CaCl}_{2}$ for $42 \mathrm{H}$ & $12.42 \mathrm{a}$ & $0.06333 \mathrm{a}-\mathrm{d}$ & 8.8378 e-h & $0.05667 \mathrm{~b}-\mathrm{e}$ \\
\hline 5 & $3 \% \mathrm{CaCl}_{2}$ for $48 \mathrm{H}$ & $11.07 \mathrm{a}-\mathrm{b}$ & $0.06667 \mathrm{a}-\mathrm{d}$ & $9.197 \mathrm{a}-\mathrm{h}$ & 0.0600 a-e \\
\hline 6 & $3 \% \mathrm{CaCl}_{2}$ for $54 \mathrm{H}$ & $11.40 a-b$ & $0.0700 \mathrm{a}-\mathrm{d}$ & $9.543 \mathrm{a}-\mathrm{f}$ & $0.0700 \mathrm{a}-\mathrm{d}$ \\
\hline 7 & $3 \% \mathrm{CaCl}_{2}$ for $60 \mathrm{H}$ & $10.45 \mathrm{~b}$ & $0.0700 \mathrm{a}-\mathrm{d}$ & $9.243 \mathrm{a}-\mathrm{g}$ & $0.0600 \mathrm{a}-\mathrm{e}$ \\
\hline 8 & $5 \% \mathrm{CaCl}_{2}$ for $24 \mathrm{H}$ & $10.59 \mathrm{~b}$ & $0.080 \mathrm{a}$ & $8.957 \mathrm{~b}-\mathrm{h}$ & $0.0700 \mathrm{a}-\mathrm{d}$ \\
\hline 9 & $5 \% \mathrm{CaCl}_{2}$ for $30 \mathrm{H}$ & $10.77 \mathrm{~b}$ & $0.0700 \mathrm{a}-\mathrm{d}$ & 9.87 a-e & $0.05667 \mathrm{~b}-\mathrm{e}$ \\
\hline 10 & $5 \% \mathrm{CaCl}_{2}$ for $36 \mathrm{H}$ & $11.14 \mathrm{a}-\mathrm{b}$ & 0.0600 a-e & $9.787 \mathrm{a}-\mathrm{f}$ & 0.0600 a-e \\
\hline 11 & $5 \% \mathrm{CaCl}_{2}$ for $42 \mathrm{H}$ & $10.93 \mathrm{a}-\mathrm{b}$ & $0.05667 \mathrm{~b}-\mathrm{c}$ & $10.02 \mathrm{a}-\mathrm{d}$ & 0.0600 a-e \\
\hline 12 & $5 \% \mathrm{CaCl}_{2}$ for $48 \mathrm{H}$ & $10.78 \mathrm{~b}$ & $0.080 \mathrm{a}$ & $9.112 \mathrm{a}-\mathrm{h}$ & $0.06667 \mathrm{a}-\mathrm{d}$ \\
\hline 13 & $5 \% \mathrm{CaCl}_{2}$ for $54 \mathrm{H}$ & $11.04 \mathrm{a}-\mathrm{b}$ & $0.06333 \mathrm{a}-\mathrm{d}$ & $9.217 \mathrm{a}-\mathrm{g}$ & 0.0600 a-e \\
\hline 14 & $5 \% \mathrm{CaCl}_{2}$ for $60 \mathrm{H}$ & $11.02 \mathrm{a}-\mathrm{b}$ & $0.07333 \mathrm{a}-\mathrm{e}$ & $9.06 a-h$ & $0.06667 \mathrm{a}-\mathrm{d}$ \\
\hline 15 & $3 \% \mathrm{ZnSO}_{4}$ for $24 \mathrm{H}$ & $11.39 \mathrm{a}-\mathrm{b}$ & $0.0700 \mathrm{a}-\mathrm{d}$ & $8.722 \mathrm{f}-\mathrm{h}$ & 0.0600 a-e \\
\hline
\end{tabular}


Table 2. Cont'd

\begin{tabular}{|c|c|c|c|c|c|}
\hline \multirow[b]{2}{*}{ No. } & \multirow{2}{*}{$\begin{array}{l}\text { Seed Priming } \\
\text { treatment }\end{array}$} & \multicolumn{4}{|c|}{ Growth parameters } \\
\hline & & $\begin{array}{l}\text { Shoot length } \\
(\mathrm{cm})\end{array}$ & $\begin{array}{c}\text { Shoot dry } \\
\text { weight (mg) }\end{array}$ & \begin{tabular}{|c}
$\begin{array}{c}\text { Root length } \\
(\mathrm{cm})\end{array}$ \\
\end{tabular} & $\begin{array}{c}\text { Root dry } \\
\text { weight }(\mathrm{mg})\end{array}$ \\
\hline 16 & $3 \% \mathrm{ZnSO}_{4}$ for $30 \mathrm{H}$ & $10.92 \mathrm{a}-\mathrm{b}$ & $0.07667 \mathrm{a}-\mathrm{b}$ & $8.093 \mathrm{~h}$ & $0.08333 a-b$ \\
\hline 17 & $3 \% \mathrm{ZnSO}_{4}$ for $36 \mathrm{H}$ & $11.19 \mathrm{a}-\mathrm{b}$ & $0.06667 \mathrm{a}-\mathrm{d}$ & 8.667 e-h & $0.08333 a-b$ \\
\hline 18 & $3 \% \mathrm{ZnSO}_{4}$ for $42 \mathrm{H}$ & $11.03 \mathrm{a}-\mathrm{b}$ & $0.05667 \mathrm{~b}-\mathrm{e}$ & $8.833 \mathrm{e}-\mathrm{h}$ & $0.06333 \mathrm{a}-\mathrm{d}$ \\
\hline 19 & $3 \% \mathrm{ZnSO}_{4}$ for $48 \mathrm{H}$ & $11.58 \mathrm{a}-\mathrm{b}$ & $0.06333 \mathrm{a}-\mathrm{d}$ & $10.03 \mathrm{a}-\mathrm{e}$ & $0.08333 a-b$ \\
\hline 20 & $3 \% \mathrm{ZnSO}_{4}$ for $54 \mathrm{H}$ & $11.24 \mathrm{a}-\mathrm{b}$ & $0.06333 \mathrm{a}-\mathrm{d}$ & 9.45 a-f & $0.0700 \mathrm{a}-\mathrm{d}$ \\
\hline 21 & $3 \% \mathrm{ZnSO}_{4}$ for $60 \mathrm{H}$ & $11.34 \mathrm{a}-\mathrm{b}$ & 0.0600 a-e & $9.29 \mathrm{a}-\mathrm{f}$ & $0.07333 \mathrm{a}-\mathrm{c}$ \\
\hline 22 & $5 \% \mathrm{ZnSO}_{4}$ for $24 \mathrm{H}$ & $10.85 \mathrm{~b}$ & $0.05333 \mathrm{c}-1$ & $10.03 \mathrm{a}-\mathrm{d}$ & 0.0600 a-e \\
\hline 23 & $5 \% \mathrm{ZnSO}_{4}$ for $30 \mathrm{H}$ & $10.46 \mathrm{~b}$ & $0.05333 \mathrm{c}-1$ & $9.347 \mathrm{a}-\mathrm{f}$ & $0.0600 \mathrm{a}-\mathrm{e}$ \\
\hline 24 & $5 \% \mathrm{ZnSO}_{4}$ for $36 \mathrm{H}$ & $10.58 \mathrm{~b}$ & $0.0500 \mathrm{~d}-\mathrm{e}$ & $0.263 \mathrm{a}-\mathrm{g}$ & $0.056667 \mathrm{~b}-\mathrm{e}$ \\
\hline 25 & $5 \% \mathrm{ZnSO}_{4}$ for $42 \mathrm{H}$ & $11.04 \mathrm{a}-\mathrm{b}$ & $0.0500 \mathrm{~d}-\mathrm{e}$ & $9.2227 \mathrm{a}-\mathrm{g}$ & $0.0700 \mathrm{a}-\mathrm{d}$ \\
\hline 26 & $5 \% \mathrm{ZnSO}_{4}$ for $48 \mathrm{H}$ & $11.23 \mathrm{a}-\mathrm{b}$ & $0.05333 \mathrm{c}-\mathrm{e}$ & $9.583 \mathrm{a}-\mathrm{f}$ & $0.06667 \mathrm{a}-\mathrm{d}$ \\
\hline 27 & $5 \% \mathrm{ZnSO}_{4}$ for $54 \mathrm{H}$ & $10.83 \mathrm{~b}$ & $0.06667 \mathrm{a}-\mathrm{d}$ & $9.667 \mathrm{a}-\mathrm{f}$ & $0.07333 \mathrm{a}-\mathrm{c}$ \\
\hline 28 & $5 \% \mathrm{ZnSO}_{4}$ for $60 \mathrm{H}$ & $10.92 a-b$ & $0.0500 \mathrm{~d}-\mathrm{e}$ & $9.673 \mathrm{a}-\mathrm{f}$ & $0.05667 \mathrm{~b}-\mathrm{e}$ \\
\hline 29 & $3 \% \mathrm{KCl}$ for $24 \mathrm{H}$ & $11.18 \mathrm{~b}$ & $0.0600 \mathrm{a}-\mathrm{e}$ & $9.0078 \mathrm{a}-\mathrm{h}$ & $0.06667 \mathrm{a}-\mathrm{d}$ \\
\hline 30 & $3 \% \mathrm{KCl}$ for $30 \mathrm{H}$ & $11.07 \mathrm{a}-\mathrm{b}$ & $0.06667 \mathrm{a}-\mathrm{d}$ & $8.92 \mathrm{c}-\mathrm{h}$ & $0.06333 \mathrm{a}-\mathrm{d}$ \\
\hline 31 & $3 \% \mathrm{KCl}$ for $36 \mathrm{H}$ & $10.06 a-b$ & $0.06333 \mathrm{a}-\mathrm{d}$ & $9.389 \mathrm{a}-\mathrm{f}$ & $0.0700 \mathrm{a}-\mathrm{d}$ \\
\hline 32 & $3 \% \mathrm{KCl}$ for $42 \mathrm{H}$ & $11.14 \mathrm{a}-\mathrm{b}$ & $0.06667 \mathrm{~d}$ & $9.617 \mathrm{a}-\mathrm{h}$ & $0.08667 \mathrm{a}$ \\
\hline 33 & $3 \% \mathrm{KCl}$ for $48 \mathrm{H}$ & $10.53 \mathrm{~b}$ & $0.05667 \mathrm{~b}-\mathrm{e}$ & $9.00 \mathrm{a}-\mathrm{h}$ & $0.05667 \mathrm{~b}-\mathrm{e}$ \\
\hline 34 & $3 \% \mathrm{KCl}_{4}$ for $54 \mathrm{H}$ & $11.06 \mathrm{a}-\mathrm{b}$ & $0.06667 \mathrm{a}-\mathrm{d}$ & $9.593 \mathrm{a}-\mathrm{f}$ & $0.0700 \mathrm{a}-\mathrm{d}$ \\
\hline 35 & $3 \% \mathrm{KCl}$ for $60 \mathrm{H}$ & $11.02 \mathrm{a}-\mathrm{b}$ & $0.0500 \mathrm{~d}-\mathrm{e}$ & $9.307 \mathrm{a}-\mathrm{f}$ & $0.05667 \mathrm{~b}-\mathrm{e}$ \\
\hline 36 & $5 \% \mathrm{KCl}$ for $24 \mathrm{H}$ & $11.06 \mathrm{a}-\mathrm{b}$ & $0.06667 \mathrm{a}-\mathrm{d}$ & 8.839 e-h & $0.06667 \mathrm{a}-\mathrm{d}$ \\
\hline 37 & $5 \% \mathrm{KCl}$ for $30 \mathrm{H}$ & $10.52 \mathrm{~b}$ & $0.06667 \mathrm{a}-\mathrm{d}$ & $8.887 \mathrm{~d}-\mathrm{h}$ & $0.07333 \mathrm{a}-\mathrm{e}$ \\
\hline 38 & $5 \% \mathrm{KCl}$ for $36 \mathrm{H}$ & $10.70 \mathrm{~b}$ & $0.053337 \mathrm{c}-\mathrm{d}$ & 9.133 a-h & 0.06667 a-d \\
\hline 39 & $5 \% \mathrm{KCl}$ for $42 \mathrm{H}$ & $10.76 \mathrm{~b}$ & $0.0600 \mathrm{a}-\mathrm{e}$ & $9.320 \mathrm{a}-\mathrm{g}$ & 0.0666 a-d \\
\hline 40 & $5 \% \mathrm{KCl}_{4}$ for $48 \mathrm{H}$ & $10.20 \mathrm{~b}$ & $0.05667 \mathrm{~b}-\mathrm{e}$ & $9.447 \mathrm{a}-\mathrm{f}$ & 0.06667 a-d \\
\hline 41 & $5 \% \mathrm{KCl}$ for $54 \mathrm{H}$ & $11.98 \mathrm{a}-\mathrm{b}$ & $0.06333 \mathrm{a}-\mathrm{d}$ & $10.14 \mathrm{a}$ & 0.07333 a-e \\
\hline 42 & $5 \% \mathrm{KCl}$ for $60 \mathrm{H}$ & $11.19 \mathrm{a}-\mathrm{b}$ & $0.0400 \mathrm{e}$ & $10.06 \mathrm{a}-\mathrm{b}$ & $0.0500 \mathrm{c}-\mathrm{e}$ \\
\hline \multirow[t]{3}{*}{43} & No Priming & $11.47 \mathrm{a}-\mathrm{b}$ & 0.0400 & 8.1478 g-h & $0.03333 \mathrm{e}$ \\
\hline & Level of Significant & NS & $* *$ & $* *$ & $* *$ \\
\hline & $\mathrm{CV}(\%)$ & 6.81 & 6.03 & 9.39 & 9.42 \\
\hline
\end{tabular}

$* *=$ Significant at $1 \%$ level of probability, $*=$ Significant at $5 \%$ level of probability, $\mathrm{CV}=$ Co-efficient of variation, NS $=$ Non significant.

\section{Root dry mass}

It is clear from (Table 2) that root dry mass of rice seedling was affected significantly due to priming treatments. The root dry mass of rice seedling for 
different treatments ranged from 0.03333 to $0.08667 \mathrm{mg}$. The highest root dry mass of rice seedlings was found in priming with $3 \% \mathrm{KCl}$ for $42 \mathrm{hrs}$. The lowest root dry mass of rice seedling was $0.0333 \mathrm{mg}$ fornon-primed seed. The results of the present study clearly showed that root dry mass of rice seedling increased by priming. From results of the present study, it may be stated that seed chemical priming treatments enhanced rapid germination and vigour index of seedling and lessen the mean germination time by different priming treatments. Therefore, the present study concludes that improvement of germination capacity and rapidity of germination of rice seed could be possible by employing priming treatment. Similar result was reported by Ruan et al. (2002).

\section{Conclusion}

Results showed that chemical priming treatments had significant effect on germination, mean germination time, vigour index of rice seeds and shoot length, shoot dry mass, root length and root dry mass of rice seedlings. Primed with $3 \%$ $\mathrm{ZnSO}_{4}$ solution for 30 hours in a remarkable technique for improving seed germination and seedling growth of rice cv. BRRI dhan 29. The no priming treatment showed the lowest germination, vigour index of rice seed and shoots dry mass, root length and root dry mass of rice seedlings and the highest mean germination time.

\section{References}

Annonymous. 2008. Agricultural Information Service. Khamarbari, Farmgate, Dhaka: Pp. 442-446.

Basar, S.M.A., Farooq, M. and Khaliq, A. 2003. Comparative study of pre-sowing seed enhanchment treatments in india rice (Oryza sativa L.). Pak.J. Life Social Sci. 1: 5-9.

Basar, S.M.A., Farooq, M. and Tabassum, R. 2005. Phvsiological and biochemical aspects of seed vigour enhancement treatments in fine rice (Oryza sativa L.). Seed Sci. Technol. 33: 623-628.

BRRI (Bangladesh Rice Research Institute) 2006. Annual research reviews report. BRRI. Gazipur, Bangladesh.

Bradford, K.J. 1986.Manipulation of seed water relations via osmotic priming to improve germination under stress conditions. Hort. Sci. 21: 1105-1112.

Farooq, M., Basar, S.M.A., Wahid, A. 2006a. Priming of field sown rice seed enhances germination, seedling establishment, allometry and yield. Plant Growth Reg. 49(2/3): 285-294.

Farooq, M., Basar, S.M.A., Ahmad, N. 2007. Improving the performance of transplanted rice by seed priming. Plant Growth Reg. 51(2): 129-137.

Farooq, M., Basar, S.M.A., Rehman, H., Ahmad, and Saleem, B.A. 2007. Osmopriming improves the germination and early seedling growth of melons (Cucumis melo L.). 
Department of Agronomy, University of Agriculture, Faisalabad-38040, Pakistan. Pakistan Journal of Agricural Science. 2007; 44(3): 529-533.

Farooq, M., Basar, S.M.A., Rehman, H., Hussain, M. 2008. Seed priming with polyamines on the germination and early seedling growth in fine rice. J. New Seeds 9(2): 145-155.

Farooq, M., Basar, S.M.A., Tabassutn, R., Afzal, I. 2006b. Enhancing the performance of direct seeded fine rice by seed priming. Plant Produc. Sci. 9(4): 446-456.

Farooq, M., De Datta,S.K., Penning, F.W.T. and Larr, E.V. 2005. Model for integrating Research in physiology, breeding and agronomy for increasing grain yield poitential. Pper presented Inter. Rice Res. Confer., 278-31. August, 2004, Seoul, Korea.

Farooq, M., Basar, S.M.A., Hafeez-ur-Rehnian, 2006c. Seed priming enhances emergence, yield and quality of direct-seeded rice. Inter.Rice Res. Notes. 31(2): $42-$ 44.

Gomez, K.A. and A.A. Gomez. 1984. Statistical Procedures for Agricural Research. Wiley Int. Sci. Pub.John Wiley Sons, New York Brisbane, Singapore. Pp.139-240.

Harris, D., Johi, A., Khan, P.A., Gothkar, P. and Sodhi, P.S. 1999. On-farm, priming in semi-arid agriculture: Development and evaluation in maize, rice and chickpea in India using paraticipatory methods. Exp. Agric. 35: 15-29.

Harris, D., Tripathi, R.S. and Joshi,A. 2000. On-seed priming improve crop establishment and yield in dry direct seeded-rice. Paper presented on seeded rice Technol. Bangkok, Thailand.

Harris, D., pathan. A.K., Gothkar. P., Joshi, A., Cliivasa. W. and Nyaniudeza, P. 2001. On-farm seed priming using parricipatory methods to revive and refine a key technology, Agric. Syst. 69: 151-164.

Lee,S.S. and Kim, J.H. 2000. Total sugars, a-amylase activity and germination after priming of normal and aged rice seeds. Korean J. Crop Sci. 43: 157-160.

Rahman, K.M., Iqbal, A. and Hasanuzzaman, M. 2008. Analysis Rice flation and Agflation. The Daily Star. 1, April, 2008, B4.

Ruan, S., Zue, Q. and Thylokowska, K. 2002. Effects of seed priming on germination and health of ricen(Oryza sativa L.) seeds. Seeds Sci. Technol. 30: 451-458.

Thomson, J.R. 1979. An introduction to Seed Technology, Thomson Litho Ltd. East Kilbride, Scotland. P. 9.

Tongma, S., Kobayashi, K., Usui, K. 2001. Allelopathic activity of Mexican sunflower [Tithonia diversifolia (Hemsl.)A. Gray] in soil under natural field conditions and different moisture conditions. Wed Biol. Management 1(2): 115-119. 